\title{
Pharmacological Properties of Presynaptic $\beta$-Adrenoceptors in Guinea-Pig Pulmonary Arteries
}

\author{
Yoshimi MISU, Masayoshi KAIHO*, Gen YASUDA**, \\ Misako KUWAHARA and Takao KUBO \\ Department of Pharmacology, Yokohama City University School of Medicine, \\ Yokohama 232, Japan \\ Accepted July 19, 1984
}

\begin{abstract}
Pharmacological properties of the facilitatory presynaptic $\beta$-adrenoceptor mechanism were studied in superfused spiral preparations of guinea-pig pulmonary arteries preloaded with ${ }^{3} \mathrm{H}$-norepinephrine. (-)-Isoproterenol $(0.3 \mu \mathrm{M})$-induced increases in total ${ }^{3} \mathrm{H}$ efflux per pulse evoked by transmural field stimulation (1, 5 , 10 and $20 \mathrm{~Hz}, 10 \mathrm{~V}, 2 \mathrm{msec}$ pulse width, 100 pulses and $30 \mathrm{~min}$ intervals) were neither dependent on impulse-frequencies nor selective at lower frequencies. Isoproterenol increased ${ }^{3} \mathrm{H}$ efflux at $5 \mathrm{~Hz}$ in a concentration-dependent manner (1 $\mathrm{nM}$ to $1 / \mathrm{M}): \mathrm{pD}_{2}$ was 7.7. Salbutamol increased ${ }^{3} \mathrm{H}$ efflux in a similar manner to isoproterenol: $\mathrm{pD}_{2}$ was 7.4. Prenalterol at $3 / \mathrm{M}$ only slightly increased ${ }^{3} \mathrm{H}$ efflux. Tazolol (10 nM to $3 \mu \mathrm{M}$ ) produced no increases. Atenolol $(3 \mu \mathrm{M})$ and practolol $(3 \mu \mathrm{M})$ did not antagonize isoproterenol $(0.3 \mu \mathrm{M})$-induced increases in ${ }^{3} \mathrm{H}$ efflux. Butoxamine $(3 / \mathrm{M})$ and $\mathrm{H} 35 / 25(3 / / \mathrm{M})$ did antagonize this parameter. (-)-Epinephrine ( $1 \mathrm{nM}$ to $0.1 \mu \mathrm{M}$ ) decreased ${ }^{3} \mathrm{H}$ efflux at $5 \mathrm{~Hz}$ and concentrationdependently increased this parameter in the presence of $10 \mu \mathrm{M}$ phentolamine. $(-)$-Norepinephrine $(10 \mathrm{nM}$ to $1 \mu \mathrm{M})$ concentration-dependently inhibited evoked ${ }^{3} \mathrm{H}$ efflux and did not increase the parameter in the presence of $10 \mu \mathrm{M}$ phentolamine, $10 \mu \mathrm{M}$ cocaine and $10 \mu \mathrm{M}$ normetanephrine. Thus, there exist presynaptic $\beta_{2}-$ subtype receptors on noradrenergic nerve endings innervating guinea-pig pulmonary arteries.
\end{abstract}

The role of presynaptic $\alpha$-adrenoceptors in the regulation of the release of the transmitter norepinephrine through a negative feedback mechanism has been well established (1-3). and it has been proposed that there is an additional facilitatory mechanism via presynaptic $\beta$-adrenoceptors (4-7). It has been considered that this presynaptic facilitatory mechanism is most sensitive at low impulsefrequencies and low biophase concentrations of norepinephrine leading to an increase in norepinephrine release (1). An alternative

\footnotetext{
* Present address: Department of Legal Medicine. Faculty of Medicine. University of Tokyo. Tokyo 113, Japan

* Present address: The 2nd Department of Internal Medicine, Yokohama City University School of Medicine, Yokohama 232. Japan
}

hypothesis is that the facilitatory mechanism is mediated by circulating epinephrine of adrenal medullary origin rather than by the positive feedback by norepinephrine (8). Misu et al. (9) demonstrated that presynaptic $\beta$-adrenoceptors are present on the surface membrane of noradrenergic nerve endings innervating guinea-pig pulmonary arteries and that low doses of (-)-propranolol inhibit transmission via blockade of these receptors.

In the present experiments, pharmacological properties of these presynaptic $\beta$ adrenoceptors were studied in the guinea-pig pulmonary arteries preloaded with ${ }^{3} \mathrm{H}$ norepinephrine to determine frequency-efflux relationships and dose-efflux relationships of relatively selective $\beta_{1}$ - and $\beta_{2}$-adrenoceptor agonists and blocking activities of relatively selective $\beta_{1}$ - and $\beta_{2}$-adrenoceptor antago- 
nists. Actions of norepinephrine and epinephrine were further studied to elucidate the endogenous role of the presynaptic $\beta$ adrenoceptor mechanism. A preliminary report has already appeared (10).

\section{Materials and Methods}

Male guinea-pigs weighing 200 to $250 \mathrm{~g}$ were sacrificed by a blow on the head, and main pulmonary arteries were excised. The spirally cut preparations were prepared as described previously (9) and were incubated at $37^{\circ} \mathrm{C}, \mathrm{pH} 7.2$ to 7.4 , for $60 \mathrm{~min}$ in Krebs bicarbonate solution, bubbled with $95 \%$ $\mathrm{O}_{2}-5 \% \quad \mathrm{CO}_{2}$, containing $0.1 \mu \mathrm{M}(-)-[7,8-$ $\left.{ }^{3} \mathrm{H}\right]$-norepinephrine $(5 \mu \mathrm{Ci} / \mathrm{ml}$, specific activity $38.6 \mathrm{Ci} / \mathrm{mmole}$. The Radiochemical Center), $5.7 \times 10^{-4} \mathrm{M}$ ascorbic acid and $4.0 \times 10^{-6} \mathrm{M}$ EDTA. The composition of Krebs' solution was as follows (in $\mathrm{mM}$ ): $\mathrm{NaCl}, 118.4 ; \mathrm{KCl}, 4.7 ; \mathrm{CaCl}_{2}, 2.5 ; \mathrm{MgCl}_{2}$, 1.18; $\mathrm{NaHCO}_{3}, 25 ; \mathrm{KH}_{2} \mathrm{PO}_{4}, 1.2$ and glucose, 11.1. After rinsing for $10 \mathrm{~min}$ with norepinephrine-free solution, the preparations were vertically mounted between a pair of platinum stimulation electrodes of $0.5 \mathrm{~mm}$ diameter and separated by $2 \mathrm{~mm}$ along the whole length of the strips (approximately $15 \mathrm{~mm}$, weighing 5 to $6 \mathrm{mg}$ ) and were superfused with Krebs' solution at a constant flow rate of $1 \mathrm{ml} / \mathrm{min}$ utilizing a microtube pump (MP-3A, Tokyo Rikakikai). The resting tension was adjusted to $0.5 \mathrm{~g}$. Transmural field stimulation with electrical rectangular pulses $(1,5,10$ or $20 \mathrm{~Hz}$. $10 \mathrm{~V}, 2 \mathrm{msec}$ pulse width, 100 pulses and usually $30 \mathrm{~min}$ intervals) was performed by use of an electrical stimulator (SEN 3201. Nihon Kohden). In all preparations, a stimulation with $1 \mathrm{~Hz}$ for $100 \mathrm{sec}$ or with $5 \mathrm{~Hz}$ for 20 sec was applied only to "condition" the strips $60 \mathrm{~min}$ after the onset of superfusion and evoked ${ }^{3} \mathrm{H}$ efflux was disregarded. A $30 \mathrm{~min}$ equilibration period was further allowed before superfusion of drug solution.

Superfusate was collected into a vial 3 times, before, during and after field stimulation, for $1 \mathrm{~min}$ in the cases with 5,10 and $20 \mathrm{~Hz}$ or for $2 \mathrm{~min}$ with $1 \mathrm{~Hz}$, respectively. ACS-II solution (Amersham/Searle) was added $(6 \mathrm{ml} / 1 \mathrm{ml}$ of the superfusate), and total ${ }^{3} \mathrm{H}$ activities expressed as disintegrations per min were determined using a liquid scintillation spectrometer (Packard 2660). Impulse-evoked increases in ${ }^{3} \mathrm{H}$ efflux were calculated as the difference between basal efflux before stimulation and total efflux detected in the successive 2 samples during and after stimulation. Isotonic contractile responses to transmural field stimulation were monitored by an inkwriting oscillograph (Biophysiograph 180 Systems, San-ei).

Drugs used were cocaine hydrochloride (Takeda); phentolamine hydrochloride (CibaGeigy); normetanephrine hydrochloride, (-)norepinephrine bitartrate, (-)-epinephrine bitartrate and (-)-isoproterenol hydrochloride (Sigma); salbutamol sulfate (Sankyo); tazolol hydrochloride (Syntex); prenalterol hydrochloride and ( \pm )-erythro-4'-methyl- $\alpha$ (1-isopropylaminoethyl) benzylalcohol hydrochloride (H 35/25) (A. B. Hässle); butoxamine hydrochloride (BurroughsWellcome); propranolol hydrochloride, atenolol hydrochloride and practolol hydrochloride $(\mathrm{ICl}) .(-)$-Norepinephrine and (-)epinephrine were dissolved in $0.06 \mathrm{~N} \mathrm{HCl}$ and the other drugs in saline. Preparations were usually exposed for $30 \mathrm{~min}$ to the superfusion medium containing drugs. Some experiments regarding $(-)$-epinephrine and $(-)$-norepinephrine were performed $30 \mathrm{~min}$ after the pretreatment with phentolamine or phentolamine, cocaine and normetanephrine.

The $\mathrm{pD}_{2}$ values of some $\beta$-adrenoceptor agonists on increases in impulse-evoked ${ }^{3} \mathrm{H}$ efflux were calculated by the methods described by Van Rossum (11). Student's t-test was used to evaluate data significance.

\section{Results}

Total ${ }^{3} \mathrm{H}$ efflux by transmural field stimulation from spirally cut pulmonary arteries preloaded with ${ }^{3} \mathrm{H}$-norepinephrine: Resting ${ }^{3} \mathrm{H}$ efflux abruptly and exponentially decreased after the beginning of superfusion with Krebs' solution (9), and that immediately before transmural field stimulation $90 \mathrm{~min}$ after superfusion was $684.3 \pm 60.1 \mathrm{dpm} / \mathrm{mg}$ wet tissue $(n=4)$. The absolute value of ${ }^{3} \mathrm{H}$ efflux varied from preparation to preparation. Transmural field stimulation at $1 \mathrm{~Hz}$ for 100 $\mathrm{sec}$ released a total ${ }^{3} \mathrm{H}$ of $818.1 \pm 30.0 \mathrm{dpm} /$ mg wet tissue/pulse. Thereafter, the amount of ${ }^{3} \mathrm{H}$ evoked by stimulation with $1 \mathrm{~Hz}$ at 
30 min intervals remained almost the same for at least 2 hr (9). As demonstrated in Fig. 1 , there was an increase in impulse-evoked efflux/pulse, as the frequency was increased from 1 to $20 \mathrm{~Hz}$.

Effects of $\beta$-adrenoceptor agonists on impulse-evoked ${ }^{3} \mathrm{H}$ efflux: (-)-Isoproterenol at $0.3 / \mathrm{M}$ significantly increased ${ }^{3} \mathrm{H}$ efflux evoked by stimulation with 100 pulses at each frequency, respectively (Fig. 2). These increases, however, were neither dependent on impulse frequencies nor selective at lower frequencies.

Resting ${ }^{3} \mathrm{H}$ efflux and impulse-evoked ${ }^{3} \mathrm{H}$ efflux with $5 \mathrm{~Hz}$ were $318.7 \pm 42.4 \mathrm{dpm} / \mathrm{mg}$ wet tissue and $1151.4 \pm 392.0 \mathrm{dpm} / \mathrm{mg}$ wet tissue/pulse $(n=6)$, respectively $90 \mathrm{~min}$ after the start of superfusion. Isoproterenol increased ${ }^{3} \mathrm{H}$ efflux evoked by impulses at $5 \mathrm{~Hz}$ in a concentration-dependent manner from $1 \mathrm{nM}$ to $1 \mu \mathrm{M}$ (Fig. 3): the calculated $\mathrm{pD}_{2}$ value was 7.7. Salbutamol markedly increased evoked efflux in a similar manner to isoproterenol: $\mathrm{pD}_{2}$ value was 7.4. On the other hand, $3 \mu \mathrm{M}$ prenalterol only slightly increased evoked efflux. Tazolol, 0.1 to $3 \mu \mathrm{M}$.

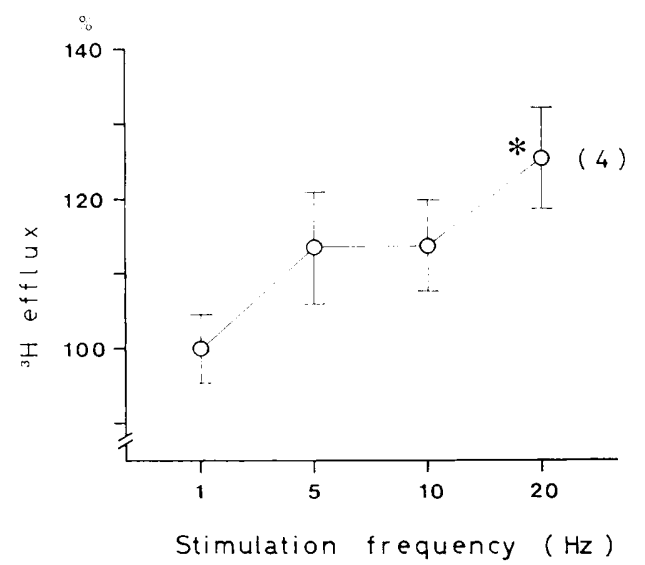

Fig. 1. Frequency-efflux relationship of impulseevoked ${ }^{3} \mathrm{H}$ efflux from spirally cut pulmonary arteries of guinea-pigs. Strips preloaded with ${ }^{3} \mathrm{H}$-norepinephrine were superfused with Krebs' solution. Ordinate shows impuise-evoked ${ }^{3} \mathrm{H}$ efflux expressed as a $\%$ of control with 100 pulses at $1 \mathrm{~Hz} 90 \mathrm{~min}$ after superfusion. Thereafter, transmural field stimulation was performed every 30 min with 100 pulses at 5,10 and then $20 \mathrm{~Hz}$. Vertical bar shows S.E. parenthesis numbers of estimations. ${ }^{*} \mathrm{P}<0.05$. compared with the control. produced no increases in the parameter.

Effects of $\beta$-adrenoceptor antagonists on isoproterenol-induced increases in impulseevoked ${ }^{3} \mathrm{H}$ efflux: Atenolol, 0.3 and $3 \mu \mathrm{M}$. and practolol, 1 and $3 \mu \mathrm{M}$, did not antagonize isoproterenol $(0.3 \mu \mathrm{M})$-induced increases in ${ }^{3} \mathrm{H}$ efflux evoked by 100 pulses at $5 \mathrm{~Hz}$ (Fig. 4). On the other hand, $3 \mu \mathrm{M}$ butoxamine and $3 / \mathrm{M} \mathrm{H} 35 / 25$ significantly antagonized this parameter.

Effects of (-)-epinephrine and (-)norepinephrine on impulse-evoked ${ }^{3} \mathrm{H}$ efflux: Epinephrine, 1 to $100 \mathrm{nM}$, inhibited ${ }^{3} \mathrm{H}$ efflux evoked by 100 pulses at $5 \mathrm{~Hz}$ in untreated tissues (Table 1). This inhibition was not concentration-dependent. Pretreatment with $10 \mu \mathrm{M}$ phentolamine markedly increased evoked efflux: a ratio of evoked efflux before and after the pretreatment was $267.5 \pm 25.5 \%$, compared to the control ratio, $94.9 \pm 0.7 \%$. In the presence of phentolamine, epinephrine concentration-dependently increased evoked efflux. On the other hand, $10 \mathrm{nM}$ to $1 \mu \mathrm{M}$ norepinephrine concentration-dependently inhibited evoked ${ }^{3} \mathrm{H}$ efflux. Pretreatment with 10 "M phentolamine under conditions of

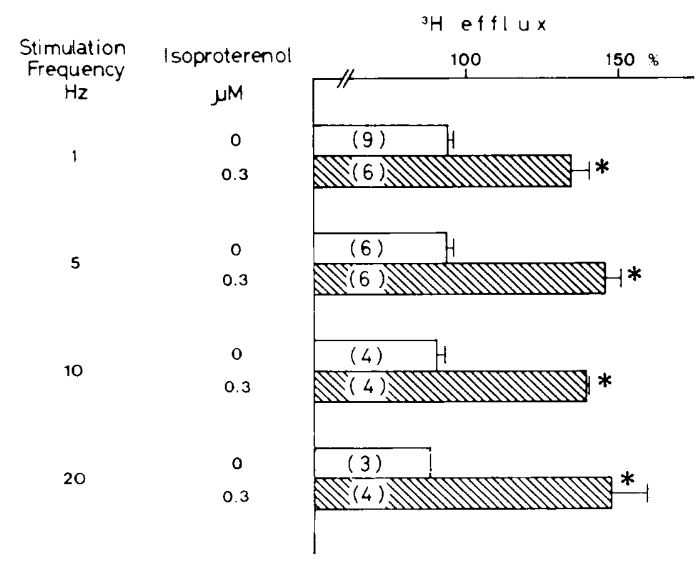

Fig. 2. Frequency-independent facilitatory actions of $0.3 \mu \mathrm{M}(-)$-isoproterenol (hatched columns) on impulse-evoked ${ }^{3} \mathrm{H}$ efflux. Isoproterenol was superfused $90 \mathrm{~min}$ after setting up strips. Stimulation at a fixed frequency of $1,5,10$ or $20 \mathrm{~Hz}$ was performed twice before $\left(S_{1}\right)$ and $30 \mathrm{~min}$ after $\left(S_{2}\right)$ the start of superfusion with isoproterenol. Abscissé shows ${ }^{3} \mathrm{H}$ efflux by $S_{2}$ expressed as a $\%$ of that by $S_{1}$. Open columns show control, horizontal bars S.E., parentheses numbers of estimations. ${ }^{*} P<0.01$, compared with $0 \mu \mathrm{M}$. Further details as in Fig. 1. 


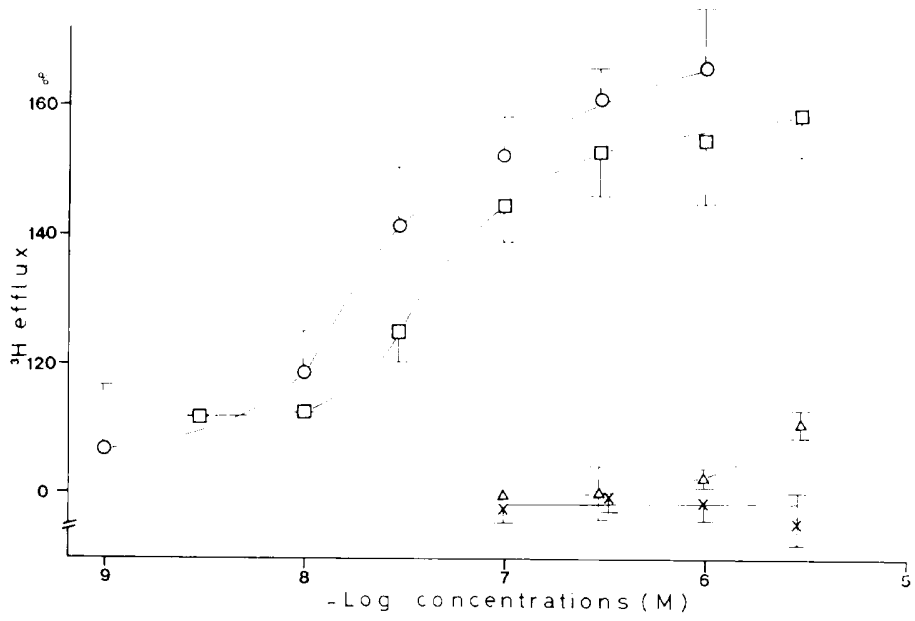

Fig. 3. Dose-efflux curves for isoproterenol (O), salbutamol $(\square)$, prenalterol $(\triangle)$ and Tazolol $(\times)$ on facilitation of impulse-evoked ${ }^{3} \mathrm{H}$ efflux. Strips were superfused with each concentration of $\beta$-adrenoceptor agonists $90 \mathrm{~min}$ after setting up. Abscissa shows - log concentrations. Stimulation was performed twice at $5 \mathrm{~Hz}$ before $\left(S_{1}\right)$ and $30 \mathrm{~min}$ after $\left(S_{2}\right)$ drug superfusion. Ordinate shows ${ }^{3} \mathrm{H}$ efflux by $\mathrm{S}_{2}$ expressed as a \% of that by $S_{1}$, which is further divided by $S_{2} / S_{1}$ efflux ratio in untreated strips demonstrated in Fig. 2. Each point represents the mean of 4 to 6 estimations. Further details as in Figs. 1 and 2.

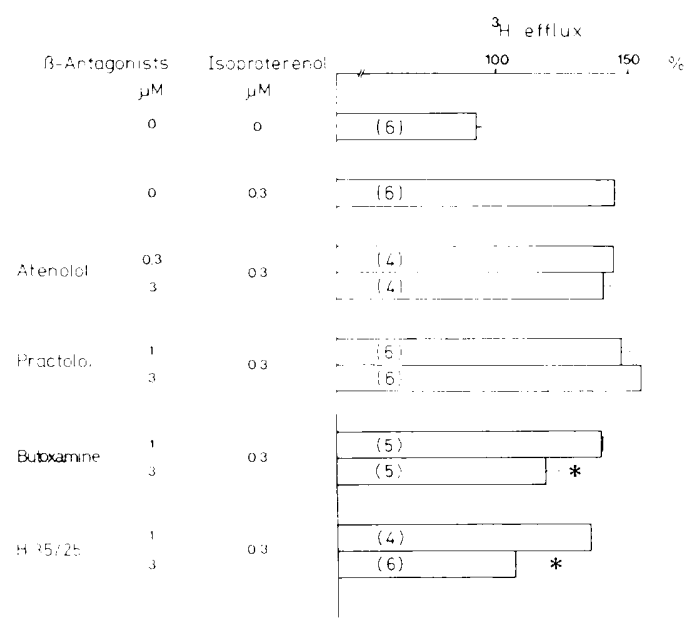

Fig. 4. Antagonizing effects of $\beta$-adrenoceptor antagonists on isoproterenol $(0.3 \mu \mathrm{M})$-induced increases in impulse-evoked ${ }^{3} \mathrm{H}$ efflux. Stimulation was done at $5 \mathrm{~Hz}$. $\beta$-Adrenoceptor antagonists were superfused simultaneously with isoproterenol. Further details as in Figs. 1 and 2.

inhibition of uptake ${ }_{1}$ and uptake $_{2}$ by $10 \mu \mathrm{M}$ cocaine and $10 \mu \mathrm{M}$ normetanephrine (12) increased the ratio of evoked efflux to 243.8 $\pm 11.6 \%$. It was difficult for phentolamine to antagonize the inhibition induced by lower concentrations of norepinephrine under these conditions, but the inhibition elicited by $1 \mu \mathrm{M}$ norepinephrine was almost completely abolished. However, no increases in evoked ${ }^{3} \mathrm{H}$ efflux over the control level were seen. The norepinephrine (1 $\mu \mathrm{M})$-induced inhibition, abolished in the presence of phentolamine, cocaine and normetanephrine, was significantly restored by the additional superfusion with $1 / \mathrm{M}(-)$-propranolol.

Resting ${ }^{3} \mathrm{H}$ efflux: It was slightly increased by epinephrine. When a ratio of resting ${ }^{3} \mathrm{H}$ efflux immediately before $S_{3}$ and $S_{2}$ periods of field stimulation in experiments shown in Table 1 was calculated, the values of the ratio $30 \mathrm{~min}$ after superfusion with 1,10 and $100 \mathrm{nM}$ epinephrine were $79.8 \pm 2.8 \%, 83.7 \pm 3.8 \%$ and $122.7 \pm 11.9 \%$, respectively, compared to the control ratio, $87.9 \pm 3.0 \%$. Increases in the parameter were not seen in the presence of phentolamine. On the other hand, norepinephrine concentration-dependently increased resting ${ }^{3} \mathrm{H}$ efflux: the values of the ratio after 10, $100 \mathrm{nM}$ and $1 \mu \mathrm{M}$ norepinephrine were $98.9 \pm 3.0 \%, 130.3 \pm 4.5 \%$ and $491.6 \pm 61.8 \%$, respectively. In the presence of phentolamine. cocaine and normetanephrine, 1 / $\mathrm{M}$ norepi- 
Table 1. Effects of epinephrine and norepinephrine on impulse-evoked ${ }^{3} \mathrm{H}$ efflux from spiral strips of guinea-pig pulmonary arteries

\begin{tabular}{|c|c|c|c|c|}
\hline Pretreatments & Agonists & Doses $(n M)$ & $N$ & $\begin{array}{l}\text { Evoked }{ }^{3} \mathrm{H} \text { efflux } \\
\left(\%, \mathrm{~S}_{3} / \mathrm{S}_{2}\right)\end{array}$ \\
\hline \multirow[t]{4}{*}{ None } & & Control & 6 & $97.1 \pm 1.6$ \\
\hline & & 1 & 4 & $77.2 \pm 5.4^{* *}$ \\
\hline & Epinephrine & 10 & 4 & $73.7 \pm 9.8^{*}$ \\
\hline & & 100 & 4 & $75.4 \pm 5.0^{* *}$ \\
\hline \multirow[t]{4}{*}{ Phentolamine } & & Control & 8 & $88.6 \pm 1.5$ \\
\hline & & 1 & 4 & $91.8 \pm 2.3$ \\
\hline & Epinephrine & 10 & 4 & $103.0 \pm 2.5^{* *}$ \\
\hline & & 100 & 4 & $131.6 \pm 7.1^{* *}$ \\
\hline \multirow[t]{4}{*}{ None } & & Control & 6 & $97.1 \pm 1.6$ \\
\hline & & 10 & 9 & $78.3 \pm 4.2^{* *}$ \\
\hline & Norepinephrine & 100 & 8 & $76.3 \pm 6.3^{* *}$ \\
\hline & & 1000 & 4 & $49.7 \pm 3.4^{* *}$ \\
\hline \multirow{4}{*}{$\begin{array}{l}\text { Phentolamine, cocaine } \\
\text { and normetanephrine }\end{array}$} & & Control & 4 & $89.1 \pm 2.3$ \\
\hline & & 10 & 6 & $72.9 \pm 4.3^{* *}$ \\
\hline & Norepinephrine & 100 & 4 & $81.6 \pm 5.7$ \\
\hline & & 1000 & 4 & $85.8 \pm 2.8$ \\
\hline $\begin{array}{l}\text { Phentolamine, cocaine, } \\
\text { normetanephrine and } \\
\text { propranolol }\end{array}$ & Norepinephrine & 1000 & 4 & $62.4 \pm 3.3^{\dagger}$ \\
\hline
\end{tabular}

Stimulation was performed three times $\left(S_{1}\right.$ to $S_{3}$ periods) with a frequency of $5 \mathrm{~Hz}$ for 20 sec at $30 \mathrm{~min}$ intervals. Evoked ${ }^{3} \mathrm{H}$ efflux by $S_{2}$ and $S_{3}$ is expressed as a $\%$ of that by $S_{1}$ and $S_{2}$, respectively. Epinephrine or norepinephrine was superfused after $\mathrm{S}_{2}$. Pretreatment with $10 \mu \mathrm{M}$ phentolamine or with $10 \mu \mathrm{M}$ phentolamine, $10 \mu \mathrm{M}$ cocaine and $10 \mu \mathrm{M}$ normetanephrine was performed after $\mathrm{S}_{1}$. (-)-Propranolol. $1 \mu \mathrm{M}$, was further superfused simultaneously with norepinephrine after $S_{2}$ in the presence of the 3 blockers. Data shown are means $\pm S$. E. of $N$ experiments. ${ }^{*} P<0.05,{ }^{*} P<0.01$, compared to the control: $\uparrow \mathrm{P}<0.01$, compared to $1 \mu \mathrm{M}$ in the presence of the 3 blockers.

nephrine alone increased this ratio $(106.0$ $\pm 5.1 \%$. compared to the control. $73.4 \pm 6.3 \%)$. These epinephrine- and norepinephrineelicited increases in resting ${ }^{3} \mathrm{H}$ efflux are probably due to blockade oi the uptake mechanism of ${ }^{3} \mathrm{H}$ norepinephrine (12).

The application of the other $\beta$-adrenoceptor agonists and the combined application of $\beta$ adrenoceptor antagonists and isoproterenol produced no modifications of resting $3 \mathrm{H}$ efflux at the range of concentrations studied.

\section{Discussion}

In spirally cut strips of guinea-pig pulmonary arteries preloaded with ${ }^{3} \mathrm{H}$ norepinephrine, the amount of total ${ }^{3} \mathrm{H}$ efflux per pulse evoked by field stimulation increased as the frequency was increased (1 to $20 \mathrm{~Hz}$ ). This result is in accordance with that in many sympathetically innervated tissues such as cat spleen (13), uterine artery (14) and vas deferens (15) of guinea-pigs and rabbit portal vein and vas deferens (16).

Isoproterenol increased impulse-evoked ${ }^{3} \mathrm{H}$ efflux. However, the increases were independent of impulse frequencies, and low frequency-selective increases such as those demonstrated in the human oviduct (17), the heart in vivo (18) and the saphenous vein in vitro (19) of dogs were not seen. Furthermore, isoproterenol increased evoked ${ }^{3} \mathrm{H}$ efflux, in a concentration-dependent manner at wide ranges from low to high concentrations (1 $\mathrm{nM}$ to $1 \mu \mathrm{M})$ : low concentration-selective increases were not seen, as those demonstrated in the human oviduct (17), the guinea-pig atria (5) and the perfused cat spleen (1). The present results show that the 
facilitatory presynaptic $\beta$-adrenoceptor mechanism is not always operative only at low frequencies of nerve stimulation and at low biophase concentrations of the transmitter norepinephrine and other adrenergic agonists. Our data appear not to be consistent with the hypothesis that a positive feedback mechanism for the transmitter release would be initiated by low biophase concentrations of norepinephrine (1).

Salbutamol, a relatively selective $\beta_{2}$ adrenoceptor agonist, produced a dose-efflux curve almost similar to that seen with isoproterenol. On the other hand, prenalterol (20) and tazolol (21), relatively selective $\beta_{1}$ adrenoceptor agonists, produced only slight or no increases in the impulse-evoked ${ }^{3} \mathrm{H}$ efflux, respectively, although it should be taken into account that these partial agonists have $\beta$-adrenoceptor blocking properties (22. 33). Atenolol (24) and practolol (25). relatively selective $\beta_{1}$-adrenoceptor antagonists, did not antagonize isoproterenolinduced increases in the evoked ${ }^{3} \mathrm{H}$ efflux within the dose ranges and at the frequency used $(5 \mathrm{~Hz})$, whereas butoxamine (26) and H $35 / 25(25,27)$, relatively selective $\beta_{2}$ adrenoceptor antagonists, antagonized this parameter. Furthermore, we confirmed that presynaptic $\beta$-adrenoceptors in guinea-pig pulmonary arteries have characteristics similar to those of postsynaptic classical $\beta$-adrenoceptors $(7,28)$. All of these results clearly demonstrate that there exist presynaptic $\beta_{2}$ subtype adrenoceptors on the surface membrane of adrenergic nerve endings innervating guinea-pig pulmonary arteries. Similar results were obtained in human omental arteries and veins (8) and in the portal vein of normotensive rats (29) and of spontaneously hypertensive rats (30). These results stand in contrast to the findings obtained in the perfused blood vessels of cat hindlimb preparations: Dahlöf et al. (31) suggested presynaptic $\beta_{1}$-subtype adrenoceptors on the basis of the inhibitory action of metoprolol on vasopressor responses to lumbar sympathetic nerve stimulation and on norepinephrine release. These results demonstrate the probability that the facilitatory presynaptic $\beta$-adrenoceptor mechanism is mediated via different subtypes in different tissues and species. Furthermore, the coexistence of presynaptic $\beta_{1}$ - and $\beta_{2}$-adrenoceptors on catecholaminergic nerve endings is demonstrated in the posterior hypothalamus of cats (32) and in the hypothalamic slices of rats $(33,34)$.

Epinephrine, an $\alpha-, \beta_{1}$ - and $\beta_{2}$-agonist, decreased evoked ${ }^{3} \mathrm{H}$ efflux and the decreases were not concentration-dependent in the absence of phentolamine, whereas the agonist readily increased in a concentrationdependent manner this parameter in the presence of phentolamine. Phentolamine unmasked a facilitatory action of epinephrine. The epinephrine-induced concentrationindependent decreases in the absence of phentolamine may be due to a balance between biphasic negative and positive feedback mechanisms on evoked efflux of the transmitter. On the other hand, norepinephrine, an $\alpha$-and $\beta_{1}$-agonist with a slight $\beta_{2}$ activity, concentration-dependently inhibited evoked ${ }^{3} \mathrm{H}$ efflux in the absence of phentolamine, cocaine and normetanephrine; and no increases in this parameter over the control level were seen even by the highest concentration of norepinephrine (1 $/ \mathrm{M})$ accompanied with increases in resting ${ }^{3} \mathrm{H}$ efflux in the presence of phentolamine, cocaine and normetanephrine. The inhibition elicited by the highest concentration of norepinephrine appears to be "fully" antagonized by phentolamine. However, this antagonism probably involves the " $\beta_{2}$-agonistic facilitotory activity" of norepinephrine for the transmitter release, since the norepinephrineinduced inhibition of ${ }^{3} \mathrm{H}$ release, abolished in the presence of phentolamine, cocaine and normetanephrine, was restored again by the additional presence of (-)-propranolol. Similar propranolol-elicited "reversal" of the effects of norepinephrine and epinephrine is also found in the presence of phenoxybenzamine in rat portal vein (30). Phentolamine alone markedly increased evoked ${ }^{3} \mathrm{H}$ efflux, which probably demonstrates that phentolamine antagonizes a negative feedback action of neuronally released norepinephrine on the transmitter release $(1-3)$. However, it was difficult for phentolamine (10 $\mu \mathrm{M})$ to antagonize the inhibition of evoked ${ }^{3} \mathrm{H}$ efflux induced by lower concentrations of 
norepinephrine. The reason for this incomplete antagonism against exogenously applied norepinephrine is not clear at present.

Concerning the role of endogenous norepinephrine and epinephrine for the presynaptic $\beta$-adrenoceptors, (-)-propranolol alone inhibited contractile responses to sympathetic nerve stimulation, whereas the $(+)$-isomer produced no inhibition of transmission and a dissociation between inhibitory actions of the (-)- and (+)isomers on evoked ${ }^{3} \mathrm{H}$ efflux was seen in the presence of phentolamine in isolated guineapig pulmonary arteries (9). These facts and results obtained in the present characterization experiments suggest that neuronally released norepinephrine can increase its own release via the facilitation of $\beta_{2}$-adrenoceptors. This idea supports to some extent the Langer hypothesis (1) that neuronally released norepinephrine is concerned in the enhancement of the transmitter release. In fact, postsynaptic vascular $\beta_{2}$-adrenoceptors can be stimulated by neuronally released norepinephrine, and resulting vasodilatation is demonstrated in the feline pulmonary vascular bed (35) and in the facial vein of the rabbits (36). However, the present results regarding exogenously applied epinephrine and norepinephrine suggest that peripheral presynaptic facilitatory $\beta$ adrenoceptors are readily activated by circulating epinephrine (8) or epinephrine taken-up and released as a cotransmitter $(19,37,38)$ rather than by norepinephrine itself released from noradrenergic nerve endings $(6,9)$. This idea is also indirectly supported by our own data that in rat hypothalamic slices, inhibitory actions of $(-)$ propranolol on impulse-evoked release of endogenous norepinephrine and dopamine were abolished when endogenous contents of epinephrine were markedly reduced by the pretreatment with 2, 3-dichloro- $\alpha$-methylbenzylamine, an inhibitor of phenylethanolamine $\mathrm{N}$-methyltransferase (34 and $\mathrm{H}$. Ueda et al., unpublished data).

In conclusion, there exist presynaptic $\beta_{2}$ subtype adrenoceptors on the adrenergic nerve endings innervating the guinea-pig pulmonary arteries.

Acknowledgements: We thank Dr. E. Carlsson.
A. B. Hässle. Sweden, for the kind supply of prenalterol and $H$ 35/25, Dr. H. C. Anderson. Synthex Corporation, U.S.A., for tazolol, and Dr. K. Murayama, Sankyo, Japan, for salbutamol. This work was partly supported by Grant No. 577114 from the Ministry of Education. Science and Culture, Japan.

\section{References}

1 Langer, S.Z.: Presynaptic receptors and their role in the regulation of transmitter release. $\mathrm{Br}$. J. Pharmacol. 60, 481-497 (1977)

2 Starke, K.: Regulction of noradrenalire release by presynaptic receptor systems. Rev. Physiol. Biochem. Pharmacol. 77, 1-124 (1977)

3 Westfall, T.C.: Local regulation of adrenergic neurotransmission. Physiol. Rev. 57, 659-728 (1977)

4 Adler-Graschinski, E. and Langer, S.Z.: Possible role of a $\beta$-adrenoceptor in the regulation of noradrenaline release by nerve stimulation through a positive feed-back mechanism. Br. J. Pharmacol. 53, 43-50 (1975)

5 Rand, M.J., Law, M., Story, D.F. and McCulloch, M.W.: Effects of $\beta$-adrenoceptor blocking drugs on adrenergic transmission. Drugs 11, Supp. 1 , 134-143 (1976)

6 Dahlöf, C.: Studies on $\beta$-adrenoceptor mediated facilitation of sympathetic neurotransmission. Acta Physiol. Scand. Supp. 500, 1-147 (1981)

7 Misu, Y. and Kubo, T.: Presynaptic $\beta$-adreroceptors. Trends Pharmacol. Sci. 4, 506-508 (1983)

8 Stjärne, L. and Brundin, J.: $\beta_{2}$-Adrenoceptors facilitating noradrenaline secretion from human vasoconstrictor nerves. Acta Physiol. Scand. 97, 88-93 (1976)

9 Misu, Y., Kaiho, M., Ogawa, K. and Kubo, T.: Adrenergic transmission failure via the blockade of presynaptic beta receptors in guinea-pig pulmonary arteries. J. Pharmacol. Exp. Ther. 218, 242-247 (1981)

10 Misu, Y., Kaiho, M. and Kubo, T.: Adrenergic trarısmission failure via the blockade of presynaptic $\beta_{2}$-receptors in guinea pig pulmonary arteries. Blood Vessels 18, 219 (1981)

11 Van Rossum, J.M.: Cumulative dose-response curves II. Technique for the making of doseresponse curves in isolated organs and the evaluation of drug parameters. Arch. Int. Pharmacodyn. Ther. 143, 299-330 (1963)

12 Iversen, L.L. and Callingham, B.A.: Adrenergic transmission. In Fundamentals of Biochemical Pharmacology, Edited by Bacq, Z.M., Ćapek, R., Paoletti, R. and Renson, J., p. 253-305, Pergamon Press, Oxford (1971) 
13 Cubeddu, L.X. and Weiner, N.: Nerve stimulation-mediated overflow of norepinephrine and dopamine- $\beta$-hydroxylase. J. Pharmacol. Exp. Ther. 192, 1-14 (1975)

14 Bell, C. and Vogt, M.: Release of endogenous noradrenaline from an isolated muscular artery. J. Physiol. (Lond.) 215, 509-520 (1971)

15 Stjärne, L.: Frequency dependence of dual negative feedback control of secretion of sympathetic neurotransmitter in guinea-pig vas deferens. Br. J. Pharmacol. 49, 358-360 (1973)

16 Hughes, J.: Evaluation of mechanism controlling the release and inactivation of the adrenergic transmitter in the rabbit portal vein and vas deferens. Br. J. Pharmacol. 44, 472-491 (1972)

17 Hedquist, P. and Moawad, A.: Presynaptic $\alpha$ and $\beta$-adrenoceptor mediated control of noradrenaline release in human oviduct. Acta Physiol. Scand. 95, 494-496 (1975)

18 Yamaguchi, N., de Champlain, J. and Nadeau, R.A: Regulation of norepinephrine release from cardiac sympathetic fibers in the dog by presynaptic $\alpha$ - and $\beta$-receptors. Circ. Res. 41 , 108-117 (1977)

19 Guimarães, S.. Brandão, F. and Paiva, M.Q.: A study of the adrenoceptor-mediated feedback mechanisms by using adrenaline as a false transmitter. Naunyn Schmiedebergs Arch. Pharmacol. 305, 185-188 (1978)

20 Carlsson, E., Dahlöf, C.-G., Hedberg, A., Persson, $H$. and Tangstrand, B.: Differentiation of cardiac chronotropic and inotropic effects of $\beta$-adrenoceptor agonists. Naunyn Schmiedebergs Arch. Pharmacol. 300, 101-105 (1977)

21 Roszkowski, A.P., Strosberg, A.M., Miller, L M., Edwards, J.A., Berkoz, B., Lewis, G.S., Halpern, O. and Fried, J.H.: Selective $\beta$-adrenergic myocardial stimulant. Experientia 28, 1336-1337 (1972)

22 Vauguelin, G., Lacombe, M.L., Guellaen, G., Strosberg, A.D. and Hanoune, J.: Tazolol (1isopropylamino-3(2-thiazoloxy)-2-propanol) as a $\beta$-adrenergic blocker. Biochem. Pharmacol. 25, 2605-2608 (1976)

23 Johansson, $U$. and Waldeck, B.: On the stereospecificity of the $\beta_{2}$-adrenoceptor blocking properties of prenalterol. J. Pharm. Pharmacol. 32, 659-660 (1980)

24 Barrett, A.M., Carter, J., Fitzgerald, J.D., Hull, R. and Le Count, D.: A new type of cardioselective adrenoceptor blocking drug. Br. J. Pharmacol. 48, 340P (1973)

25 Levy, B. and Wilkenfeld, B.E.: An analysis of selective beta receptor blockade. Eur. J. Phar- macol. 5, 227-234 (1969)

26 Levy, B.: The adrenergic blocking activity of $\mathrm{N}$ tert-butylmethoxamine (Butoxamine) J. Pharmacol. Exp. Ther. 151, 413-422 (1966)

27 Carlsson, E., Ablad, B., Brändström, A. and Carlsson, B.: Differentiated blockade of the chronotropic effects of various adrenergic stimuli in the cat heart. Life Sci. 11, 953-958 (1972)

28 Misu, Y., Kuwahara, M., Kaiho, M. and Kubo, T.: Further characterization of presynaptic $\beta$ adrenoceptors in guinea-pig pulmonary arteries. Eur. J. Pharmacol. 91, 287-290 (1983)

29 Westfall, T.C., Peach, M.J. and Tittermary, V.: Enhancement of the electrically induced release of norepinephrine from the rat portal vein: mediation by $\beta_{2}$-adrenoceptors. Eur. J. Pharmacol. 58, 67-74 (1979)

30 Dahlöf, C., Ljung, B. and Ablad, B.: Pre- and postjunctional beta-adrenoceptor mediated effects on transmitter release and effector response in the isolated rat portal vein. Acta Physiol. Scand. 108, 39-47 (1980)

31 Dahlöf, C., Ảblad, B., Borg, K.O., Ek, L. and Waldeck, B.: Prejunctional inhibition of adrenergic nervous vasomotor control due to $\beta$ receptor blockade. In Chemical Tools in Catecholamine Research II, Edited by Almgren, O., Carlsson. A. and Engel, J., p. 201-210. North-Holland, Amsterdam (1975)

32 Dietl, H., Sinha, J.N. and Philippu, A.: Presynaptic regulation of the release of catecholamines in the cat hypothalamus. Brain Res. 208, 213-218 (1981)

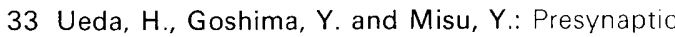
mediation by $\alpha_{2}-\beta_{1}$ - and $\beta_{2}$-adrenoceptors of endogenous noradrenaline and dopamine release from slices of rat hypothalamus. Life Sci. 33, 371-376 (1983)

34 Ueda, H., Goshima, Y., Kubo, T. and Misu, Y.: Adrenaline involvement in the presynaptic $\beta$ adrenoceptor-mediated mechanism of dopamine release from slices of the rat hypothalamus. Life Sci. 34, 1087-1093 (1984)

35 Hyman, A.L., Nandiwada, P., Knight. D.S. and Kadowitz, P.J.: Pulmonary vasodilator responses to catecholamines and sympathetic nerve stimulation in the cat. Circ. Res. 48, 407-415 (1981)

36 Pergram, B.L., Bevan, R.D. and Bevan, J.A.: Facial vein of the rabbit. Neurogenic vasodilation mediated by $\beta$-adrenergic receptors. Circ. Res. 39, 854-860 (1976)

37 Majewski, H., McCulloch. M.W., Rand, M.J. and Story, D.F.: Adrenaline activation of prejunctional $\beta$-adrenoceptors in guinea-pig atria. 
Br. J. Pharmacol. 71, 435-444 (1980)

38 Majewski H. and Rand, M.J.: An interaction between prejunctional $\alpha$-adrenoceptors and prejunctional $\beta$-adrenoceptors. Eur. J. Pharmacol. 69, 493-498 (1981) 